\title{
PENDIDIKAN KARAKTER BANGSA
}

\author{
Ahmed Machfudh \\ Sekolah Tinggi Agama Islam ALHIKMAH Jakarta
}

\section{Abstract}

Besides the efforts to enhance the knowledge of science and technology as well as work ethic and competitiveness, the efforts to establish the character and identity of nation are implemented through the development of religion in the form of providing education in order to realize an independent Indonesian society that is advanced, noble, dignified, and civilized. The development in the field of religion cannot be separated from the development of education, especially religious education and education in Islamic school (madrasah) and other religious public educational institutions. The development of the nation's character is directed to be part of efforts to achieve the vision of the national development as it is stated in the Long Term Development Plan of 2005-2025 namely to make Indonesia as a developed, independent, and fair nation as the foundation for the next stage of development toward fair and prosperous society in the NKRI (a unitary state of Indonesia) based on the Pancasila and the Constitution of the Republic of Indonesia 1945.

Keywords : education, character education, religious education, and the nation's character. 


\section{Abstrak:}

Upaya pembentukan karakter dan jati diri bangsa, di samping peningkatan penguasaan dan ketrampilan di bidang ilmu pengetahuan dan teknologi serta peningkatan etos kerja dan daya saing, dilaksanakan melalui pembangunan agama dalam bentuk penyelenggaraan pendidikan guna mewujudkan masyarakat Indonesia yang mandiri, maju, berakhlak mulia, bermartabat, danberadab.Pembangunanbidangagamatidakdapatdilepaskan dari pembangunan pendidikan, khususnya pendidikan agama, pendidikan keagamaan, dan pendidikan pada madrasah serta lembagapendidikan umum lainnya yang bercirikhaskeagamaan. Pembangunan karakter bangsa diarahkan menjadi bagian yang tak terpisahkan dari upaya pencapaian visi pembangunan nasional sebagaimana tertuang dalam Rencana Pembangunan Jangka Panjang Tahun 2005-2025, yaitu mewujudkan Indonesia sebagai bangsa yang maju, mandiri, dan adil sebagai landasan bagi tahap pembangunan berikutnya menuju masyarakat adil sebagai landasan bagi tahap pembangunan berikutnya menuju masyarakat adil makmur dalam NKRI beradasarkan Pancasila dan Undang-Undang Dasar Negara Republik Indonesia Tahun 1945.

Kata kunci: Pendidikan, pendidikan karakter, pendidikan agama, karakter bangsa 
Masyarakat bangsa akan memiliki akhlak luhur bila unsurterkecilnya yaitu setiap individu berperilaku dengan akhlak yang terpuji. Jika akhlak terpuji sirna dalam masyarakatniscaya hancurlahmasyarakat tersebut. [Ahmad Syauqi Bek]

\section{A. PENDAhuluan}

$\mathrm{B}$ angsa Indonesia dikenal sebagai bangsa yang sangat menjunjung tinggi norma dan nilai agama serta keluhuran adat istiadat yang berlaku dalam masyarakat. Namun kini sikap luhur tersebut jarang (untuk tidak mengatakan tidak) nampak dalam masyarakat Indonesia. Masyarakat Indonesia kini dikenal sebagai masyarakat yang tengah mengalami "krisis sosial budaya" atau "krisis peradaban" yang sangat memprihatinkan. Fenomena korupsi, penyalahgunaan narkoba, perjudian, pembunuhan, kenakalan remaja, pornografi dan pornoaksi, pergaulan bebas, dan berbagai konflik sosial merupakan sejumlah contoh realitas krisis dimaksud yang terjadi di tengah kehidupan bangsa Indonesia.

Pada tataran sosial teologis dapat dirasakan bersama bahwa kualitas keberagamaan sebagian masyarakat masih memprihatinkan. Berdasarkan refleksi terhadap realitas kehidupan keberagamaankeseharianmasyarakatdisatupihakdanpengamalan terhadap realitas sosial yang terjadi di lain pihak, ternyata kualitas pemahaman, penghayatan, dan pengamalan agama masyarakat Indonesia cenderung masih rendah. Hal tersebut disebabkan oleh faktor penyerapan dan penghayatan negatif terhadap nilai-nilai modernitas oleh masyarakat. Pemujaan terhadap akal pikiran, persepsi berlebihan terhadap kecanggihan ilmu pengetahuan dan teknologi, pola hidup yang berorientasi pada hedonisme, dan nilai kepraktisan yang diusung oleh modernisme mengakibatkan pertumbuhan orientasi, persepsi, sikap, dan gaya hidup yang mengabaikan nilai-nilaiagama.

Memang tak dapat dipungkiri bahwa di bidang pendidikan dan kebudayaan tampak pembangunan fasilitas pendidikan secara masif, penyediaan sarana prasarana pendidikan dan 
keikutsertaan masyarakat yang luas di dalam proses pendidikan bangsa. Namun masih terdapat persoalan yang sangat serius, khususnya pendidikan yang belum berhasil menanamkan karakter bangsa karena telah mengabaikan budi pekerti yang memberi dasar bagi pertumbuhan peserta didik menjadi manusia yang memiliki karakter dan kemandirian. Fenomena yang terjadi adalah orientasi pendidikan pada perolehan kelulusan formal, belum pada penguasaan substansi atau kompetensi, pemecahan masalah, dan kepedulian sosial. Bahkan ada satuan pendidikan yang memberikan nilai "murah" kepada peserta didiknya dalam ujian akhir agar terkesan bahwa satuan pendidikan tersebut mendapat peringkat nomor atas lantaran seluruh peserta didiklulus, atau paling tidak masyarakat "dipaksa" mengakui kebanggaan semu yang diraihnya. Kondisi sepertiitu bertolak belakang dengankeadaan satu dekade sebelumnya, ketika seringkali seorang kepala sekolah diancam oleh peserta didik yang tidak lulus dalam ujian akhir.

Perkembangan kebudayaan nampak lebih berorientasi kepada materialisme dan sekularisme. Pada saat yang sama, aspek spiritualisme dan akal sehat dilupakan. Akibatnya, kehidupan pemimpin dan masyarakat kehilangan kedalaman makna, kemuliaan akhlak, kepedulian kepada sesama, serta kepekaan nurani. Hal ini yang mengakibatkan masyarakat berperilaku munafik, kolutif, dekaden, dan koruptif.

Berbagai perkembangan yang terjadi meliputi aspek politik, hukum, ekonomi, pendidikan, dan kebudayaan menunjukkan kontradiksi yang cukup memprihatinkan. Kemajuan-kemajuan yang dicapai ternyata disertai penggerusan nilai-nilai luhur bangsa Indonesia. Kondisi ini tidak boleh dibiarkan tanpa suatu upaya sadar dan sungguh-sungguh untuk mengembalikan nilai-nilai luhur tersebut sebagai tenaga pendorong pencapaian kemajuan dalam setiap segi kehidupan oleh segenap komponen bangsa. Sebagai salah satu komponen bangsa yang memiliki komitmen terhadap nasib bangsa, kita tidak boleh mendiamkan keadaan tersebut terjadi berlarut-larut. Kita memiliki tanggungjawab untuk mendorong pelaksanaan langkah-langkah nyata agar proses 
penggerusan itu berhenti dengan cara menjadikan agama sebagai sumber utama moralitas, etik, dan spiritualitas dalam kehidupan bermasyarakat, berbangsa, dan bernegara. Masyarakat bangsa yang kehilangan pijakan moral, etik, dan spiritual sesungguhnya adalah masyarakat yang rapuh dan akan mengalami disorientasi.

Oleh karenaitu kualitas keberagamaan kita haruslah didasari dengan moral dan akhlak yang mulia. Tugas untuk membangun moral bangsa sebenarnya bukan hanya tanggung jawab pemerintah, tetapi tanggung jawab masing-masing dari kita semua sebagai warga masyarakat. Karena itu sejak April 2010 pemerintah mulai memikirkan untuk melakukan revitalisasi pendidikan karakter bangsa. Berbagai kementerian dan lembaga dilibatkan untuk menyusun gagasan pendidikan karakter bangsa yang diharapkan dapat membuahkan ide dan modus cemerlang guna mengusung moral bangsa ke arah yang lebih baik dalam menjaga eksistensi bangsa Indonesia. Suatu bangsa atau institusi akan dapat langgeng ketika memiliki moralitas dan kredibilitas yang tinggi. Seorang penyair Mesir yang peduli akan pendidikan akhlak, Ahmad Syauqi Bek memberikan petuah, ${ }^{1}$

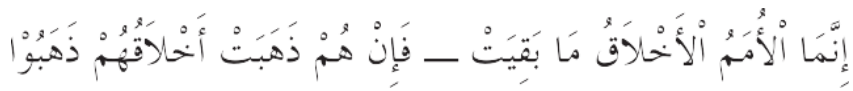

Artinya:

Sesungguhnya eksistensi suatu bangsa ditentukan oleh moralitas dan akhlak mulia. Jika moralitas menjadi panglima maka jayalah bangsa. Sebaliknya jika moralitas rendah, maka tunggulah kehancurannya.

Barometer akhlak mulia bagi individu, keluarga, masyarakat, maupun negara sekurang-kurangnya terlihat dari perwujudan kasih sayang, kebersamaan, perhatian, saling menghormati, dan kejujuran. Kehidupan individu, keluarga, masyarakat, dan negara yang tidak terbangun kasih sayang, kebersamaan, perhatian, saling menghormati, dan kejujuran dalam sistem hidupnya hanya tinggal menunggu kehancuran. Akhlak mulia adalah landasan yang paling mendasar dalam membangun kebudayaan dan peradaban umat

\footnotetext{
436

${ }^{1}$ Al-Syanqiỵ̣̂Muhammad Amin, Aựva 'al-Bayān, (Dār Alimal-Kutub, t.t.), vol. 8 h.
} 
manusia. Akhlak mulia yang hilang dalam sistem kehidupan umat manusiaberartikehilanganharapanbagiperwujudankesejahteraan, baik lahir maupun batin. Karena sebaik-baik manusia adalah orang yang memiliki keunggulan akhlak mulia.

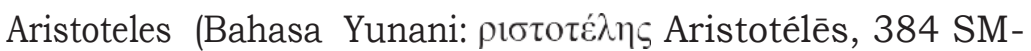
$322 \mathrm{SM}$ ) seorang filosof Yunani menjelaskan bahwa kenakalan atau akhlak tercela dapat diubah dengan cara pendidikan menuju kebaikan, meskipun tidak mutlak. Menurut Abu Ali Ahmad bin Muhammad bin Yakub Ibnu Miskawayh (wafat $421 \mathrm{H}$.), seorang tokoh filsafat akhlak, ketika mengomentari pernyataan Aristoteles tersebut menyatakan bahwa setiap akhlak pada dasarnya memang dapat diubah. ${ }^{2}$ Karena itu diperlukan pendidikan, terutama sejak masa kanak-kanak atau sejak usia masih muda. ${ }^{3}$ Memang diakui oleh Ibnu Miskawayh bahwa terkadang akhlak sulit diubah karena memang sudah menjadi watak seseorang. Kesulitan pengubahan watak yang demikian beliau ibaratkan seperti mengubah "perilaku" api yang cenderung ke atas menjadi ke bawah, atau "perilaku" batu yang cenderung ke bawah diubah menjadi ke atas. ${ }^{4}$

Mengapa pendidikan akhlak yang merupakan dasar utama dalam pendidikan karakter bangsa diperlukan sejak dini yaitu masa kanak-kanak?. Hal ini dapat dipahami bahwa kebiasaan anakadalah meniru apa saja yang dilihat atau didengar. Mereka melakukannya secara mudah tanpa dengan susah payah, tanpa paksaan, dan tanpa dipikirkan, tidak seperti orang dewasa atau orang tua. Dengan demikian pembentukan akhlak akan lebih mudah, karena akhlak adalah kondisi kejiwaan yang menyebabkan perbuatan-perbuatan keluardengan mudah, tanpa susah payah, dan tanpa paksaan. ${ }^{5}$

Kementerian Agama sebagai lembaga pemerintah yang diberi amanatdalambidangkeagamaanbersama-samadenganmasyarakat

\footnotetext{
${ }^{2}$ Ibn Miskawayh, Tahż̄̇bul Akhlāq, Digital e-book dari http:/ / www.alwarraq.com, h. 12, diakses pada 10 Desember 2010

${ }^{3}$ Muchlis M. Hanafi, et.al., Pendidikan, Pembangunan Karakter, dan Pengembangan Sumber Daya Manusia, (Jakarta: Lajnah Pentashihah Mushaf al-Quran, 2010), h. 10

${ }^{4}$ Ibn Miskawayh, Tahdżībul Akhlāq, h. 12

${ }^{5}$ Abu Hamid Muhammad ibn Muhammad ibn Muhammad al-Ghazaliy, Tazkiyatul Qalb 'an al-Akhlāq al-Mażmūmah, saduran Ahmed Machfudh (Jakarta: t.p., 2010), h. 1
} 
dan tokoh-tokoh agama telah berusaha mengembangkanlembagalembaga dan pendidikan keagamaan. Upaya yang dilakukan yaitu dengan melaksanakan pendidikan karakter bangsa sehingga mampu melahirkan manusia berkualitas dan memiliki daya saing yang andal serta mampu melahirkan tokoh-tokoh yang dapat membangun moral/karakter bangsa menuju baldatut ayyibatun wa rabbun ghafür, yaitu negara yang gemah ripah loh jinawi serta mendapat ridhaTuhan.

Karakter berasal dari bahasa Inggris character yang salah satu artinya adalah ( $n$. \{U\}[of a person, community, race, etc.] mental or moral nature; mental or moral qualities that make one person, race, etc. different from others). ${ }^{6}$ Karakter adalah kumpulan tata nilai yang mewujud dalam suatu sistem daya dorong yang melandasi pemikiran, sikap, dan perilaku yang akan ditampilkan secara mantap. Karakter merupakan aktualisasi potensi dari dalam dan internalisasi nilai-nilai moral dari luar yang menjadi bagian kepribadian seseorang. Karena karakter harus diwujudkan melalui nilai-nilai moral yang dipatrikan agar menjadi semacam nilai intrinsik dalam diri yang akan melandasi sikap dan perilaku, maka karakter harus dibentuk, ditumbuhkembangkan, dan dibangun. ${ }^{7}$

Berhasilkah lembaga dan pendidikan keagamaan dalam pembangunan karakter bangsa? Bagaimana sikap keberagamaan yang terjadi di masyarakat? Jika kita amati, nampaknya terjadi disparitas tajam antara personal religiousity sebagai basis pembangunan akhlak mulia dengan social religiousity sebagai konsekuensi beragama. Bahkan lebih parah lagi terjadi pemisahan antara sikap keberagamaan di masjid, gereja, atau rumah-rumah ibadah dengan tingkah laku di kantor-kantor pemerintahan dan swasta, di jalan raya, di pasar, di ranah bisnis dan sebagainya. Padahal jelas bahwa seseorang seharusnya tetap beragama di mana saja. Agama hanya berlaku saat seseorang berada di masjid atau di atas sajadah dan rumah ibadah lainnya. Ketika berada di kantor

\footnotetext{
${ }^{6}$ A.S. Hornby, E.V. Gatenby, and H. Wakefield, The Advanced Learner's Dictionary of Current English, (Great Britain, The Oxford University Press, 1973), h. 156

${ }^{7}$ Soemarsono Soedarsono, "Membangun Kembali Jati Diri Bangsa: Arti dan Peran Penting Karakter Hasrat untuk Berubah," dalam Harian Umum Pelita, edisi20 Juli 2009
} 
atau di tempat lain banyak yang berperilaku seolah-olah ajaran agama tidak berbekas sama sekali.

Ambil contoh kecil tentang perilaku membuang sampah sembarangan atau perilaku para pengendara kendaraan bermotor dijalan yang menyerobot. Mereka mengaku sebagai orang beragama (Islam). Mereka tahu bahwa agama menganjurkan keindahan dan kebersihan. Mereka tahu bahwa kriteria seorang muslim adalah orang yang membuat nyaman muslim lainnya atau tidak membuat orang muslim lain terancam oleh ketajaman lidahnya dan perilakunya sesuai hadits $\mathrm{Nabi}^{8}$

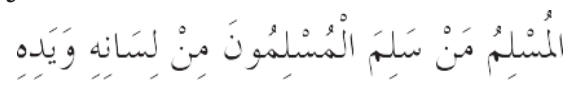

Artinya:

Orang muslim adalah yang membuat orang muslim lainnya aman dari lisan dan tangannya).

Namun mereka masih saja membuat orang lain tidak nyaman. Oleh karena itu sudah saatnya dilakukan revolusi mental berupa perubahan mendasar atas pranata, lembaga, dan kebijakan publik yang berlandaskan kepatutan etika, moral, dan akal sehat dengan merealisasikan dan mengimplementasikan nilai-nilai agama dalam perilaku sehari-hari. Berbagai upaya yang dilakukan untuk membangun karakter bangsa diharapkan dapat membuahkan hasil optimal dalam mengembalikan bangsa Indonesia sebagai bangsa yang sangat menjunjung tinggi norma dan nilai agama serta keluhuran adat istiadat yang berlaku dalam masyarakat.

\section{B. PEMBAHASAN}

\section{Pendidikan Karakter sebagai IsuStrategis}

Revitalisasi pembangunan karakter bangsa yang dijadikan pangkal upaya guna mengembalikan bangsa yang menjunjung

${ }^{8}$ Muslimibnal-Hajjaj,ShahihMuslim,(t.k.:Daral-Kutubal-Ilmiah, 1992), vol. 2, h. 10. Riwayat dari Hasan al-Hulwaniy dan Abd ibn Humaid dari Abu Ashim dari Ibn Juraij dari Abu az-Zubair dari Jabir ra. Hadits yang senada juga diriwayatkan oleh al-Bukhariy, Ahmad, at-Turmudziy, ad-Darimiy, Abu Dawud, Ibn Hibban, al-Bayhaqiy, an-Nasaiy, atThabraniy dan lain-lain dalam shahih, musnad, dan sunan mereka. 
norma dan nilai agama sebagaimana dimaksud diatas didasarkan atas beberapa kenyataan yang terjadi, seperti: (a)disorientasi dan nilai-nilai Pancasila sebagai filosofi dan ideologi bangsa belum dihayati; (b)keterbatasan perangkat kebijakan terpadu dalam mewujudkan nilai-nilai esensi Pancasila; (c)pergeseran nilai etika dalam kehidupan berbangsa dan bernegara; (d) pemudaran kesadaran terhadap nilai-nilai budaya bangsa; (e) ancaman disintegrasi bangsa; dan (f)kemandirian bangsayang melemah.

Nilai-nilai dalam pembangunan karakter bangsa yang menjadi topik program/kegiatan antara lain: agamis, jujur, amanah, terpercaya, sabar, tabah, keteladanan, ramah, santun, saling menghargai, gotong royong, kebersamaan, tidak anarkis, tertib, kerja keras, menghormati orang tua-guru-pimpinan, mau berbagi, empati, toleransi dalam kehidupan beragama, berjiwa kebangsaan (tidak etnosentris), tidak primordial, bertanggung jawab, cerdas dan berprestasi, kompetitif (berdaya saing), bersih dan hemat, peduli, kosmopolit, berani mengambil resiko, pantang menyerah, rela berkorban, mengutamakan kepentingan umum, cinta tanah air (patriotisme), serta bangga menggunakan bahasa dan produk Indonesia. Karakter bangsa yangdiharapkanberdasarkanfalsafah Pancasilayangdiwujudkan melalui pembangunan karakter individu warga negara adalah hasil perpaduan olah hati, olah pikir, olah raga, serta olah rasa dan karsa. Olah hati berkenaan dengan perasaan sikap dan keimanan dengan aktualisasi karakter antara lain beriman dan bertakwa, jujur, amanah, adil, tertib, taat aturan, bertanggung jawab, berempati, berani ambil risiko, pantang menyerah, rela berkorban dan berjiwa patriotik. Olah pikir berkenaan dengan proses nalar guna mencari dan menggunakan pengetahuan secara kritis, kreatif dan inovatif, dengan aktualisasi karakter antara lain cerdas, kritis, kreatif, inovatif, ingin tahu, produktif, berorientasi ilmu pengetahuan, teknologi dan seni, dan reflektif. Olah raga berkenaan dengan proses persepsi, kesiapan, peniruan, manipulasi, dan penciptaan aktivitas baru disertai dengan sportivitas dengan aktualisasi karakter antara 
lain berupa bersih dan sehat, sportif, tangguh, andal, berdaya tahan, bersahabat, kooperatif, determinatif, kompetitif, ceria, dan gigih. Sedangkan olah rasa dan karsa berkenaan dengan kemauan dan kreativitas yang tercermin dalam kepedulian, citra dan penciptaan kebaruan dengan aktualisasi karakter antara lain berupa kemanusiaan, saling menghargai, gotong royong, kebersamaan, ramah, hormat, toleran, nasionalis, peduli, kosmopolit, bangga menggunakan bahasa dan produk Indonesia, dinamis, kerja keras, dan beretos kerja.

\section{Warisan Nilai Luhur}

Kita patut bersyukur ditakdirkan sebagai bangsa Indonesia yang memiliki keragaman budaya, suku, agama, dan ras. Warisan budaya dan nilai-nilai luhur yang diwariskan kepada kita menjadi patokan dalam menata kehidupan berbangsa dan bernegara yaitu Pancasila. Para pendahulu bangsa telah menetapkan Pancasila sebagai filosofi untuk landasan dalam kehidupan berbangsa dan bernegara yang menjadi rujukan serta menjiwai setiap langkah perbuatan baik secara pribadi sebagai warga bangsa maupun dari sisi kelembagaan dalam proses kehidupan berbangsa dan bernegara. Oleh karena itu Pancasila harus dihayati dan dipedomani oleh seluruh warga negara dalam hidup dan kehidupan bermasyarakat, berbangsa, dan bernegara, sehinggamenjadiidentitasataujatidiribangsa Indonesia.

Kita perlu membuka kembali dan belajar dari warisan sejarah bangsa. Sebuah kerajaan besar di Nusantara yang pernah berkuasa sekitar lima abad memiliki semboyan terkenal dan diabadikan oleh para pendiri Negara Republik Indonesia yakni Bhinneka Tunggal Ika Tan Hana Dharma Mangrwa. Kita adalah berbeda-beda tapi tetap satu. Keberagaman itu harus dipandang sebagai kekayaan khazanah sosiokultural, kekayaan kodrati dan alamiah sebagai anugerah Tuhan, bukan untuk dipertentangkan apalagi dipertantangkan yang dapat mengakibatkan bangsa terpecahbelah. Bagaimanamemasyarakatkankembalisemboyan ini dan menumbuhkan toleransi terhadap keberagaman yang 
ada dalam masyarakat?. Bila semua warga bangsa tidak dapat mengidentifikasi diri sebagai orang Indonesia dapat dipastikan akan menjumpai kesulitan untukmencapai titik temu. Apalagi jika semua orang berpijak secara ekstrim pada landasan ideologi atau agama masing-masing.

Arus globalisasi telah memacu pertukaran arus manusia, barang, dan informasi tanpa batas. Hal ini berdampak terhadap penyebarluasan pengaruh budaya dan nilai-nilai termasuk ideologi dan agama dalam suatu bangsa yang sulit dikendalikan. Pada gilirannya hal itu dapat mengancam jatidiri bangsa. Perkembangan ilmu pengetahuan dan teknologi khususnya teknologi telekomunikasi telah memungkinkan manusia melakukan komunikasi global tanpa dibatasi oleh ruang dan waktu. Perkembangan yang terjadi di negara lain dalam waktu yang singkat dapat diketahui. Kepesatan bidang teknologi komunikasi tersebut telah membawa perubahan besar di berbagai sektor kehidupan manusia dan berdampak pada pergeseran nilai dan perilaku kehidupan masyarakat.

Perubahan pola pikir di bidang ekonomi dan politik telah melahirkan perubahan nilai-nilai yang dianut masyarakat. Kondisi tersebut menyebabkan disorientasi yangberdampak kepada pergeseran penghayatan terhadap nilai-nilai Pancasila. Hal ini mengakibatkan perkembangan materialisme yang menonjolkan kedaerahan dan kelompok masing-masing serta abai memikirkan hal yang dibutuhkan oleh bangsa. Oleh karena itu pengembangan jatidiri bangsa yang berpijak dari warisan budaya bangsa berlandaskan pada sendi-sendi agama yang diyakini masing-masing menjadi pilar penting pemersatu bangsa. Kondisi ini sangat diperlukan agar tercipta sebuah negara kesatuan yang utuh, aman, dan damai.

Komitmen terhadap Negara Kesatuan Republik Indonesia (NKRI) adalah kesepakatan final yang perlu lebih dipertegas dalam pembangunan karakter bangsa. Karakter yang dibangun pada manusia dan bangsa Indonesia adalah karakter yang memperkuat dan memperkukuh komitmen terhadap NKRI, 
bukan sebaliknya yang berkembang tidak terkendali dan menggoyahkan NKRI. Oleh karena itu dalam pembangunan karakterbangsaperludikembangkanpilar-pilarakhlakataumoral yang diejawantahkan dalam diri seseorang sehingga menjadi orang yang berkarakter jujur, sabar, rendah hati, tanggung jawab, dan rasa hormat yang tercermin dalam masyarakat yang harmonis dan dinamis. Rasa cinta terhadap tanah air atau patriotisme, sikap demokratis, dan menjunjung tinggi hakasasi manusia menjadi bagian dari pembangunan karakter bangsa. Kesemuanya harus diletakkan dalam bingkai menjunjung tinggi persatuan dan kesatuan bangsa atau nasionalisme.

Warisan nilai-nilai kearifan yang diturunkan dari para pendahulu antara lain sikap saling bekerja sama antara penguasa dan rakyat. Penguasa bertanggung jawab dan menjamin kesejahteraan rakyat. Rakyat bertanggung jawab menjaga kewibawaan masyarakat. Untuk menjaga kewibawaan masyarakat perlu ditumbuhkan toleransi sebagai penghargaan terhadap keberagaman yang ada dalam masyarakat. Masyarakat Indonesia yang mayoritas Islam juga tetap kokoh pada ajaran agamanya yaitu taat kepada penguasa sebagaimana disebutkan dalam al-Quranal-Karim ${ }^{9}$ :

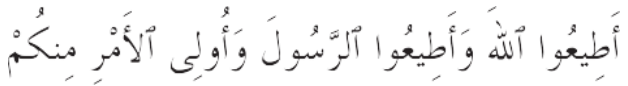

Artinya:

Taatilah Allah dan taatilah Rasul serta ulil amri/penguasa kamu.

Dalam hadits juga disebutkan bahwa taat kepada penguasa atau pimpinan berarti taat kepada Rasul saw ${ }^{10}$ :

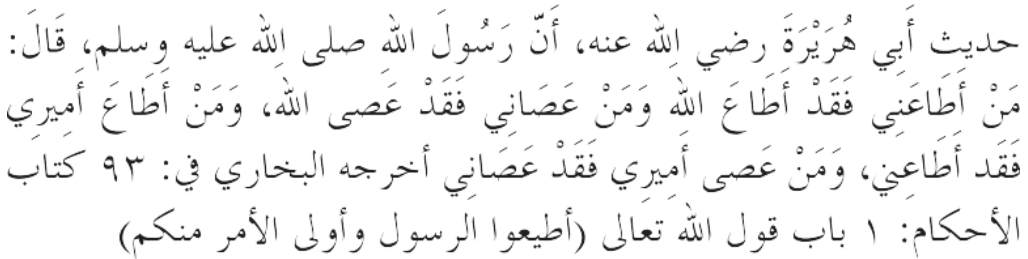

${ }^{9}$ Al-Quran al-Karim, Surat an-Nisā, ayat 59

${ }^{10}$ Muhammad Fuad AbdulBaqiy, al-Lu'lul'waal-Marjān, (Beyrut: Darul Fikr, 1997), vol. 1 , h. 597 
Artinya:

Hadits Riwayat al-Bukhariy dari Abu Hurayrah ra dalam mengulas firman Allah 'Taatilah Rasul serta ulil amri/penguasa kamu' bahwa Rasulullah saw bersabda, "Barang siapa taatkepada saya berarti taat kepadaAllahdan barang siapa durhakakepada sayaberartidurhaka kepada Allah. Barang siapa taat kepada pemimpinku berarti taat kepadaku dan barang siapa durhaka kepada pemimpinku berarti durhaka kepadaku.)

Namun ketaatan yang dimaksud adalah dalam hal yang positif. Jika sebaliknya, maka Rasul saw tidak akan mengakui sebagaiumatnya ${ }^{11}$ sebagaimana tertera dalam hadits:

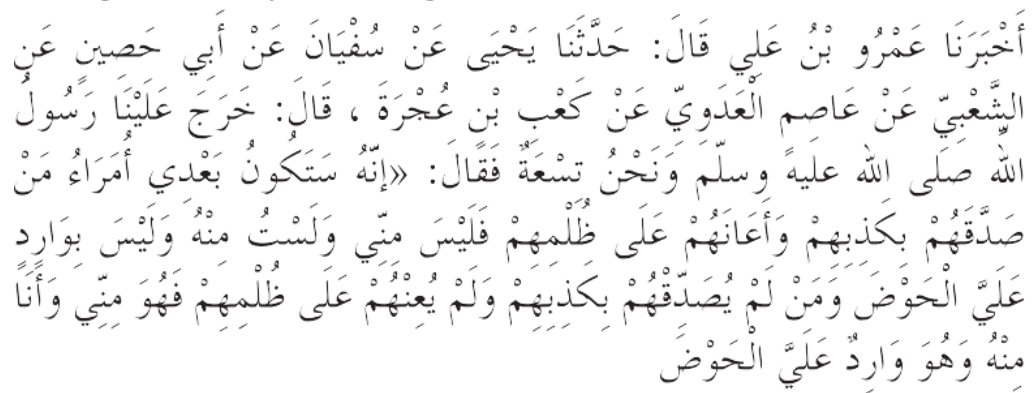

Artinya:

Dari Amr bin Ali, dari Yahya, dari Sufyan, dari Abi Hashin, dari alSya 'biy, dari Ashim al-Adawiy, dari Ka'b bin Ujrah berkata, "Kami keluar bertujuh bersama Rasul saw, beliau bersabda, "Nanti setelah aku akan muncul para pemimpin. Barang siapa membenarkan kedustaannyadanmenolongkedhalimannya, makaiatidaktermasuk golonganku dan tak akan sampai ke telagaku. Barang siapa yang menyangkal kedustaannya dan tak mau membantu kedhalimannya, maka ia adalah golonganku dan nanti akan sampai ke telagaku."

\section{Pembangunan Bidang Agama}

Pembangunan karakter bangsa dapat dikembalikan kepada pembangunan bidang agama. Karakter, moral, atau akhlak yang dijiwai dan didasarkan atas ajaran agama merupakan

\footnotetext{
${ }^{11}$ Al-Nasa'i, Sunan al-Nasa'i al-Sughra, digital e-book, vol. 7, h. 180
} 
keniscayaan yang tak terbantahkan. Ada beberapa filosofi yang dijadikan landasan dalam pembangunan bidang agama, yaitu (a)agama sebagai sumber nilai spiritual, moral, dan etik bagi kehidupan berbangsa dan bernegara, (b)penghormatan dan perlindungan atas hak dan kebebasan beragama sebagai bagian dari hak asasi warga negara, (c)kerukunan umat beragama dan tata kelola kehidupan beragama, (d)pengembangan karakter dan jatidiribangsa, dan (e)penyediaan fasilitasi dan pelayanan bagi umat beragama berdasarkan prinsip tata kelola kepemerintahan yang baik.

Sasaran pembangunan bidang agama antara lain adalah (a) peningkatan kualitas kehidupan beragama agar masyarakat memiliki karakter yang bagus, (b)peningkatan kerukunan umat beragama agar masyarakat hidup dalam kedamaian, (c)peningkatan kualitas pendidikan agama dan pendidikan keagamaan guna penguatan akhlak atau budi pekerti, (d) peningkatan kualitas penyelenggaraan ibadah haji agar masyarakat dapat berperilaku positif dalam setiap keadaan sesuai dengan titel hajinya, dan (e)tata kelola kepemerintahan yang bersih dan berwibawa sebagai wujud perilaku pengalaman ajaran agama di lingkungan pemerintah agar tidak berperilaku koruptif. ${ }^{12}$ Keberagamaan, ketakwaan, dan akhlak mulia dari tiap individu, masyarakat, dan seluruh warga negara merupakan target dan sasaran pembangunan.

Agama memiliki kedudukan dan peran yang sangat penting dalam kehidupan bangsa Indonesia. Pengakuan akan kedudukan dan peran penting agama tercermin dari penetapan prinsip Ketuhanan Yang Maha Esa sebagai sila pertama falsafah negara, yangjuga dipahami sebagai silayang menjiwai sila-sila Pancasila lainnya. Oleh sebab itu pembangunan agama bukan hanya merupakan bagian integral pembangunan nasional, melainkan juga bagian yang seharusnya melandasi dan menjiwai keseluruhan arah dan tujuan pembangunan nasional. Contoh

${ }^{12}$ Departemen Agama RI, Meningkatkan Kualitas Kehidupan Beragama, Pendidikan Agama dan Keagamaan, (Jakarta: Departemen Agama, 2009), h. 2-5 
kecil adalah pembuatan polisi tidur yang selayaknya tidak dibuatoleh sembarang orang dan di berbagaijalankarenatidak sesuai dengan ajaran agama seperti ilustrasi berikut. Persoalan kecelakaan lalu lintas mengundang keprihatinan berbagai kalangan. Hal itu disebabkan antara lain karena pengendara yang tidak sopan berlalu lintas dan/atau pengguna jalan lainnya yang tidak tertib. Akhirnya tidak hanya pihak kepolisian, masyarakat pun melakukan berbagai upaya guna meminimalisasi bahkan menghindari terjadinya kecelakaan lalu lintas tersebut. Diantara upaya yang dilakukan mereka adalah membuat rintangan di jalan berupa polisitidur. Masyarakat pun menjadidungu, rambu kecepatan maksimal tidak pernah dipasang, cukup dihalang dengan polisi tidur yang membuat komponen kendaraan cepat rusak. Bolehkah seseorang yang mengaku muslim membuat atau memasang polisi tidur di jalan? Menurut beberapa referensi seperti I'änah at -Ṭhālibìn volume III halaman 84, al-Muhażżab volume II halaman 193, Is 'àd ar-Rofiq volume II halaman 133, dan al-Iqnā' volume II halaman 320 hal itu tidak diperbolehkan. Kebolehan membuat polisi tidur jika jalan itu berada di pelosok (bukan jalan PUD), itupun dengan catatan: (1)para pengguna jalan tidak merasa terganggu, (2)mendapat ijin resmi dari Pemerintahyang berwenang, (3)memperoleh kesepakatan dari warga sekitar, dan (4)dibuat sesuai dengan petunjuk teknis Peraturan Pemerintah Nomor 43 Tahun 1993 pasal 35 ayat (1) yaitu tinggi maksimal $10 \mathrm{~cm}$, lebar minimal $60-70 \mathrm{~cm}$, diberi tanda zebrabiru-putih. ${ }^{13}$

Selain memiliki posisi yang sangat penting agama juga menempati posisi unik dalam kehidupan berbangsa dan bernegara. Hal ini tercermin dalam suatu rumusan terkenal tentang hubungan antara agama dan negara di Indonesia. Indonesia bukanlah negara teokratis, tetapi bukan pula negara sekular. Rumusan ini berarti bahwa tatanan kehidupan berbangsa dan bernegara tidak didasarkan pada satu paham atau keyakinan agama tertentu, namun nilai-nilai keluhuran, keutamaan, dan kebaikan yang terkandung dalam agama-agama

\footnotetext{
${ }^{13}$ Peraturan Pemerintah Nomor 43 Tahun 1993 tentang Prasarana Lalu Lintas Jalan
} 
diakui sebagai sumber dan landasan spiritual, moral, dan etik bagi kehidupan bangsa dan negara.

Pembangunan karakter bangsa diarahkan menjadi bagian yang tak terpisahkan dari upaya pencapaian visi pembangunan nasional sebagaimana tertuang dalam Rencana Pembangunan Jangka Panjang Tahun 2005-2025, yaitu mewujudkan Indonesia sebagai bangsa yang maju, mandiri, dan adil sebagai landasan bagi tahap pembangunan berikutnya menuju masyarakat adil sebagai landasan bagi tahap pembangunan berikutnya menuju masyarakat adil makmur dalam NKRI beradasarkan Pancasila dan Undang-Undang Dasar Negara Republik Indonesia Tahun 1945.

Cita-cita nasional untuk mencerdaskan kehidupan bangsa dilandasi keinginan menjadikan Indonesia sebagai bangsa yang maju, unggul, mandiri, bermartabat, beradab, dan sejahtera. Untuk mewujudkan hal itu telah diusahakan dan diselenggarakan suatu sistem pendidikan nasionalyang dapat membentuk manusia Indonesia yang memiliki penguasaan dan keterampilan yang tinggi dalam bidang ilmu pengetahuan dan teknologi, memiliki etos kerja dan daya saing, serta memiliki karakter dan jatidiri bangsayang kuat, dengan bertumpu pada keimanan dan ketakwaan serta akhlak yang mulia.

Upaya pembentukan karakter dan jati diri bangsa, di samping peningkatan penguasaan dan ketrampilan di bidang ilmu pengetahuan dan teknologi serta peningkatan etos kerja dan daya saing, dilaksanakan melalui pembangunan agama dalam bentuk penyelenggaraan pendidikan guna mewujudkan masyarakat Indonesia yang mandiri, maju, berakhlak mulia, bermartabat, dan beradab. Pembangunan bidang agama tidak dapat dilepaskan dari pembangunan pendidikan, khususnya pendidikan agama, pendidikan keagamaan, dan pendidikan pada madrasah serta lembaga pendidikan umum lainnya yang berciri khas keagamaan. Pendidikan agama dan pendidikan keagamaan merupakan salah satu program prioritas pembangunan bidang agama. Penetapan prioritas tersebut didasarkan pada kebutuhan 
berupa (a)ketersediaan layanan pendidikan agama yang bermutu bagi semua peserta didik pada semua jenis, jenjang, dan satuan pendidikan, (b)ketersediaan lembaga pendidikan yang menghasilkan ahli agama yang menguasai dan mengamalkan ajaran agama secara komprehensif, mendalam, dan profesional, (c)ketersediaan program pendidikan agama dan lembaga pendidikan keagamaan yang bermutu bagi masyarakat dalam rangka mencerdaskan dan meningkatkan kualitas kehidupan bangsa serta daya saing nasional.

Perlu disadari bahwa agama bukanlah sekadar mengajarkan tentang hubungan antara pemeluk agama dan Sang Pencipta, melainkan juga tentang hubungan antar sesama manusia dan hubungan dengan alam sekitarnya. Oleh sebab itu pembangunan bidang agama diarahkan bukan saja untuk meningkatkan kualitas kesalehan individual umat beragama, tetapi juga mendorong perwujudan kesalehan sosial dan ekologis, serta moralitas publik dalam pengelolaan kehidupan bernegara. Sikap toleran dan penghormatan terhadap pandangan dan keyakinan orang lain, kepedulian terhadap sesama manusia, serta kerjasama, dan tolong menolong adalah sebagian dari wujud dari kesalehan sosial. Sementara itu pemanfaatan dan pendayagunaan sumber daya alam disertai perlindungan dan pemeliharaan kelestariannya antara lain merupakan bentukbentuk nyata dari kesalehan ekologis. Adapun moralitas publik dalam kehidupan bernegara antara lain termanifestasi dalam penyelenggaraan perundang-undangan yang berlaku, serta terbebas dari perilaku koruptif dan menyimpang.

\section{Alasan Revitalisasi Pendidikan Karakter Bangsa (PKB)}

Ada beberapa alasan yang mendasari mengapa diperlukan revitalisasi pendidikan dan pembangunan karakter bangsa. Ditinjau dari segi filosofis, PKB diperlukan karena kebutuhan asasi dalam proses berbangsa yang secara ideologis merupakan upaya pengejawantahan ideologi Pancasila dalam kehidupan berbangsa dan bernegara. Secara normatif PKB adalah wujud 
nyata langkah mencapai tujuan negara karena secara historis hal tersebut merupakan dinamika inti proses kebangsaan yang terjadi tanpa henti. Sedangkan dari segi sosiokultural PKB merupakan keharusan daribangsayang multikultural.

Jika kita tinjau kondisi masyarakat bangsa Indonesia, nampaknya telah terjadi pergeseran nilai etika dan nilai budaya yang antara lain disebabkan oleh berbagai faktor seperti kesenjangan sosial ekonomi dan politik, ketidakadilan hukum, pergaulan bebas dan pornografi, tindak kekerasan dan kerusuhan, korupsi di semua sektor kehidupan, tindakan anarkis dan tidak santun, abai terhadap prinsip musyawarah, serta kearifan lokal, toleransi, dan gotong royongyang berubah menjadi hegemoni kelompok yang saling menyalahkan. Fenomena keseharian menunjukkan perilaku masyarakat belum sejalan dengan karakter bangsa yang dijiwai oleh falsafah Pancasila seperti budaya instant dan konsumtif. Hal tersebut antara lain disebabkan oleh keajegan perhatian terhadap pembangunan karakter bangsa yang belum terjaga dengan baik, sehingga hasilnya belum optimal. Karena itu diperlukan revitalisasi $\mathrm{PKB}$.

Beberapa rujukan yang dapat dipergunakan untuk menyusun kebijakan dalam PKB adalah (a)Undang-Undang Nomor 17 Tahun 2007 tentang Rencana Pembangunan Jangka Panjang Nasional 2005-2025, (b)Instruksi Presiden Nomor 1 Tahun 2010 tentang Percepatan Pelaksanaan Prioritas Pembangunan Nasional Tahun 2010, (c)arahan Presiden RI dalam Sidang Kabinet Terbatas Bidang Kesra tanggal 18 Maret 2010, (d) arahan Presiden RI pada Rapat Kerja Nasional di Tampak Siring, Bali tanggal 19-20 April 2010, dan (e)arahan Presiden RI pada Puncak Peringatan Hari Pendidikan Nasional di Istana Negara tanggal 11 Mei 2010.

Tujuan PKB adalah mengembangkan karakter bangsa agar mampu mewujudkan nilai luhur Pancasila melalui pengembangan potensi dasar agar berhati, berpikiran, dan 
berperilaku baik, perbaikan terhadap perilaku yang kurang baik, dan penguatan perilaku yang sudah baik, serta penyaringan budaya yang kurang sesuai dengan nilai luhur Pancasila. Ruang lingkupnyaadalahkeluarga, satuanpendidikan, masyarakatsipil, masyarakat politik, pemerintah, dunia usaha dan dunia industri, serta media massa. Intinya adalah membangun generasi yang jujur, cerdas, tangguh, dan peduli. Karakter yang diharapkan adalah sesuai dengan Undang-Undang Nomor 17 Tahun 2007 tentang Rencana Pembangunan Jangka Panjang Nasional 20052025 yaitu tangguh, kompetitif, berakhlak mulia, bermoral, bertoleran, bergotong royong, patriotik, dinamis, berbudaya, dan berorientasi ilmu pengetahuan dan teknologi berdasarkan Pancasila dan dijiwai oleh iman dan takwa kepada Tuhan Yang Maha Esa.

\section{Strategi PKB}

Ada lima strategi yang diperlukan dalam pembangunan karakter bangsa, yaitu sosialisasi, pendidikan, pemberdayaan, pembudayaan, dan kerjasama. Sosialisasi dimaksudkan sebagai upaya penyadaran semua pemangku kepentingan akan kepentingan karakter bangsa. Media massa perlu berperanserta dalam sosialisasi. Strategi melalui pendidikan diselenggarakan melalui pendidikan formal (satuan pendidikan), nonformal (kegiatan keagamaan, kursus, pramuka dan lain-lain), informal (keluarga, masyarakat, dan tempat kerja), dan forum pertemuan seperti kepemudaan. Pemberdayaan karakter bangsa dilakukan terhadap semua pemangku kepentingan yaitu orang tua, satuan pendidikan, organisasi massa, dan sebagainya agar berperan aktif dalam pendidikan karakter. Perilaku berkarakter dibina dan dikuatkan dengan penanaman nilai kehidupan agar menjadi budaya. Sedangkan strategi terakhir adalah kerjasama, yaitu membangun kerjasama yang sinergis antara semua pemangku kepentingan.

Bagaimana strategi PKB melalui pendidikan diselenggarakan? Nilai-nilai luhuryang terdapat dalam ajaran agama, Pancasila, 
teori pendidikan, psikologi, nilai sosial budaya, serta pengalaman terbaik dan praktik nyata dimasukkan dalam lingkup satuan pendidikan, keluarga, dan masyarakat baik melalui intervensi maupunhabituasi. Prosestersebutmerupakanpembudayaandan pemberdayaan yang didukung dengan kebijakan, sumberdaya, sarana dan prasarana, kebersamaan, dan komitmen para pemangku kepentingan. Hasil akhir yang diharapkan adalah perilaku berkarakter yang sesuai dengan nilai-nilailuhur.

Bagaimana pelaksanaan pendidikan karakter di madrasah atau sekolah? Kegiatan keseharian di madrasah dan sekolah harus dijadikan sebagai laboratorium yaitu penerapan akhlak mulia dan nilai-nilai luhur bangsa. Hal ini melibatkan seluruh komponen sekolah, sehingga tanggung jawab pembentukan moraldanakhlakmuliabukanhanyaolehgurupendidikanagama saja. Dalam kegiatan belajar mengajar, akhlak mulia dan nilai luhur tersebut diintegrasikan ke dalam setiap mata pelajaran, sehingga semua guru bertanggung jawab atas pendidikan karakter anak didiknya. Pembiasaan dalam keseharian di satuan pendidikan berarti penerapan akhlak mulia dan nilai luhur tidak hanyasaatkegiatanbelajarmengajarsaja. Bahkandalamkegiatan ekstra kurikuler pun akhlak mulia dan nilai luhur dimaksud harus diintegrasikan seperti dalam kegiatan pramuka, olahraga, karya tulis, dan lain sebagainya. Jika perilaku keseharian di madrasah atau sekolah sudah terlaksana, maka perlu dijaga agar penerapan pembiasaan kehidupan keseharian di rumah selaras dengan yang dilakukan di satuan pendidikan.

Apabila hal di atas terlaksana, maka kemajuan di berbagai bidang kehidupan masyarakat yang meliputi bidang sosial budaya dan kehidupan beragama, ekonomi, ilmu pengetahuan dan teknologi, politik, pertahananan dan keamanan, hukum dan aparatur, pembangunan wilayah dan tata ruang, penyediaan sarana dan prasarana, serta pengelolaan sumber daya alam dan lingkungan hidup tidak akan tercemari oleh perilaku menyimpang. 


\section{PENUTUP}

Dalam Undang-Undang Nomor 20 tahun 2003 tentang Sistem Pendidikan Nasional pemerintah merumuskan bahwa tujuan pendidikan nasional adalah mengembangkan kemampuan dan membentuk watak serta peradaban bangsa yang bermartabat dalam rangka mencerdaskan kehidupan bangsa, bertujuan untuk berkembangnya potensi peserta didik agar menjadimanusiayang beriman dan bertakwa kepada Tuhan Yang Maha Esa, berakhlak mulia, sehat, berilmu, cakap, kreatif, mandiri, dan menjadi warga negara yang demokratis serta bertanggung-jawab. Rumusan tersebut terdengar sangat ideal. Namun dalam pelaksanaannya terlihat jauh dari yang dicita-citakan. Mencerdaskan kehidupan bangsa bukanlah sekadar upaya mengasah kecerdasan otak, namun merupakan upaya mencerdaskan agar bangsa dapat hidup bermartabat, berbudi luhur, sehat jasmani dan rohani, dan memiliki tanggung-jawab sosial. Jadi, pendidikan di Indonesia dilaksanakan dengan maksud tidak hanya mengembangkan ilmu pengetahuan dan ketrampilan saja, namun juga mengembangkan nilai-nilai luhur yang melekat pada diri yang didasarkan pada keimanan dan ketakwaan yang secara nyata harus dapat dilihat dalam langkah solidaritas kemanusiaan. Dengan kata lain, pendidikan harus berfungsi sebagai sarana untuk transfer and production of knowledge, values, and social solidarity atau sebagai alat penyalur dan pengembang ilmu pengetahuan, nilai-nilai luhur, dan solidaritas sosial.

Pendidikan bukanlah berfungsi sebagai proses transfer ilmu pengetahuan semata, namun juga sebagai transfer dan stimulator pengembangan nilai-nilai luhur seperti nilai-nilai jujur, adil, demokratis, disiplin, terbuka, dan toleran. Oleh karena itu peran guru dituntut tidak saja mumpuni dalam pengetahuan dan pandai dalam mengajar, tetapijuga dapat menjadi teladan dan acuan dari nilai-nilai luhur yang akan ditularkan pada anak didik. Transfer nilai-nilai luhur kepada anak didik agar dijadikan pegangan hidup tidak cukup hanya ditularkan dengan anjuran atau perintah, namun yang lebih penting adalah keteladanan. Integritas guru menjadi 
penting karena nilai-nilai luhur yang harus ditransfer guru dan didorong untuk dikembangkan kepada anak didik mustahil akan mudah dicerna bila guru yang mengajarkan berperilaku kontradiktif dengan apa yang diajarkannya. Oleh karena itu laboratorium agama, yaitu membuat situasi keseharian di madrasah atau sekolah melalui aplikasi ajaran agama dan akhlak mulia perlu dilaksanakan.

Penegakan nilai-nilai luhur akan sulit dilakukanoleh orang per orang. Karena itu yang dapat dikembangkan adalah membangun aturan-aturan pengendali perilaku (dapat berupa tata tertib ataupunkodeetik) yangdisusunsecarajelasdandisepakatibersama. Tata tertib ataupun kode etik yang diterapkan harus dijalankan secara konsisten dan demokratis sehingga upaya sosialisasi dan penerapan nilai-nilai luhur memiliki dampak kolektif yang baik. Dengan demikian, lingkungan satuan pendidikan merupakan pulau-pulau integritas yang menjadi acuan penegakan perilaku yang didasarkan pada nilai-nilai luhur itu. Dengan nilai-nilai luhur yang terinternalisasi dalam diri anak didik dalam lingkungan pulaupulau integritas, akan tercipta identitas pikiran, perilaku, dan kalbu yang memiliki karakter yang jelas dan tegas. Jika pendidikan karakter berhasil, mungkin hal-hal sepele yang tidak sesuai dengan ajaran agama seperti orang yang membuat rintangan di jalan (polisi tidur) dan membuat sebagian besar pengendara kendaraan merasakesaldanjengkel tidakadalagi, dan tidakakan terlihatlagi orangyang membuang sampah rumah tangga di pinggirjalan saat melintas dengan sepeda motornya.[] 


\section{DAFTAR REFERENSI}

Al- Quran al-Karim, digital Quran

al-Ghazaliy, Abu Hamid Muhammad ibn Muhammad ibn Muhammad, Kitab al-Arba'īn fì Ushūl al-Dìn. Beirut: Darul Kutub al-Alamiyyah , Abu Hamid Muhammad ibn Muhammad ibn Muhammad, Tazkiyatul Qalb 'an al-Akhlāq al-Mażmümah, saduran Ahmed Machfudh, Jakarta: t.p., 2010

Al-Nasaiy, Sunan al-Nasaiy al-Sughra, digital e-book

Amin, al-Syanqithy Muhammad, dwa'al-Bayān. t.k.: Dar Alim alKutub, t.t.

Baqiy, Abdul, Muhammad Fuad, al-Lu'lul'wa al-Marjān, Beirut: Darul Fikr, 1997

Departemen Agama RI, Meningkatkan Kualitas Kehidupan Beragama, Pendidikan Agama dan Keagamaan, Jakarta: Departemen Agama, 2009

Hanafi, Muchlis M., et.al., Pendidikan, Pembangunan Karakter, dan Pengembangan Sumber Daya Manusia, Jakarta: Lajnah Pentashihah Mushaf al-Quran, 2010

Ibn Miskawayh, Abu Ali Ahmad bin Muhammad bin Ya'kub, Tahżìbul Akhlāq, Diakses dari www.alwarraq.com

Muslim ibn al-Hajjaj, Shahīh Muslim, t.k. : Dar al-Kutub al-Ilmiah, 1992

Peraturan Pemerintah Nomor 43 Tahun 1993 tentang Prasarana Lalu Lintas Jalan

Undang-Undang Nomor 17 Tahun 2007 tentang Rencana Pembangunan Jangka Panjang Nasional 2005-2025 
160 HIKMAH, Vol. XIII, No. 2,2017 